\title{
Opening an electronic pharmacy to the world
}

Despite the optimism about the potency of the new AIDS drugs, there is substantial concern that the prohibitive cost will prevent many from benefiting from them. Furthermore, the drugs are not.

\section{Mideast cancer coalition stalls}

Four months after it was announced with much fanfare, the first governmental medical collaboration between Israel and its Middle Eastern neighbors appears to be on the rocks. Known as the Middle East Cancer Consortium (MECC), the effort involving Cyprus, Egypt, Israel, Jordan and the Palestinian Authority - was launched to improve health care and promote regional scientific projects in the field of cancer (see Nature Medicine 2, 727).

But the undertaking ran into trouble early. The first MECC meeting in July was marked by the conspicuous absence of the Egyptian and Palestinian delegations. A spokesman for the Israeli Health Ministry said the Palestinians hinted the reason was political. But Munzer Sharif, deputy health minister of the Palestinian Authority, said that he and the other Palestinian delegate had received the invitation at too short a notice (it is still not clear why the Egyptians failed to show).

Apart from the poor attendance, the meeting did not move things along. Several Palestinians and Israelis supposed to play leading roles in the consortium told Nature Medicine they had received no feedback from the July gathering, and in fact were unaware of any consortium activities since it was officially formed on May 20.

Michael Silbermann, the Israeli representative to MECC, was extremely optimistic about the effort at its launch. But now he refuses interviews, citing a "sensitive political situation," referring to the uncertainty about the future of Israeli-Arab relations since the Likud government came to power in the spring.

However, Sharif says that other joint projects between Israeli and Palestinian health authorities continue "in a very good manner," and does not know what is halting the flashier MECC effort.

LUBA VIKHANSKI Rehovot, Israel world to get the new AIDS drugs because they weren't available." Thus, the idea behind AIDSH is to provide the same drugs at a slightly lower cost (five percent) than the average price charged in US pharmacies, plus the cost of shipping (less than the cost of flying to the USA in person).

Although AIDSR has only existed since July, it has already run into

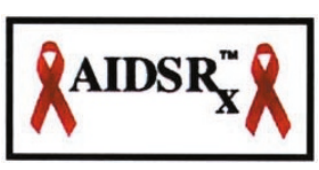

the size of that market (that is, people who don't have health insurance but can still pay for the drugs) is not likely to be large.

All that is required to order the drugs from AIDSR is "a legitimate prescription in English," says the spokesman. "We checked it out a result, physicians worldwide can now have prescriptions for scarce AIDS drugs filled and shipped to them by the new company, which its founders have named "AIDSB ," and which is available via the World wide Web (http://www aidsdrugs.com).

"It was formed out of an idea we got from a newspaper story," says one founding member, who asked not to be named because of professional ties to another corporation. "The article mentioned that people were flying to the US from all over the problems. The most significant of these is the fact that many countries have stringent restrictions on importing drugs. "The bureaucracy at the other end has really slowed us down," said the AIDSB spokesman. "Physicians in many countries have to contact their country's minister of health to get things through."

But the enquiries are increasing rapidly. "We've had calls from Cameroon, Kenya, Taiwan and India," says the spokesman. "And the Indian doctor said he represented 20,000 patients." Furthermore, the company has decided to start selling drugs at a discount to US patients who don't have insurance to pay for them, although long as we could get a legitimate could get a legitimate prescription, we could sell it here and ship it to anywhere that would accept it." North Carolina law, unlike many other states' laws, does not prohibit such transactions.

AIDSB is a for-profit business, but not a money-making opportunity, according to its founders. Furthermore, the AIDSR founders intend to invest ten percent of their profit from any order into AIDS education efforts in the country from which the order was received. "We're not trying to get rich off this," says the spokesman, "but we do think there is room for this to grow."

F.R.S.

\section{Varmus names insider as director of NIGMS}

National Institutes of Health director Harold Varmus has appointed Marvin Cassman as director of the National Institute of General Medical Sciences. Cassman, the tenth new NIH institute director appointed by Varmus since he took over the reigns in 1993, is a NIGMS insider, having served in various capacities at NIGMS since 1975. The last three years he has been the acting director of the institute, overseeing a US $\$ 947$ million budget that funds research grants in basic biomedical science.

"It is not an easy time for science," says Cassman, "and that's part of what makes the job interesting." He believes that NIGMS has "specific responsibility" for the "long-term health of basic biomedical research and the research community." To that end,

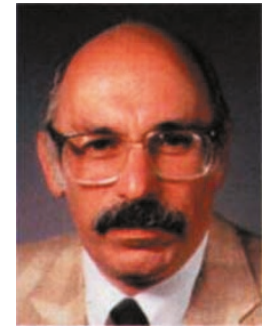

Marvin Cassman, NIGMS director Cassman says that his main concerns include the "perceived in-

stability of the system" (that is, fluctuations in levels and types of funding), widespread fears that "the system has gotten too conservative" (favoring safe ideas over novel approaches), and the difficulties faced by new investigators in obtaining funding in an increasingly competitive environment.

In announcing the appointment, Varmus noted that Cassman has "proven himself astute at perceiving trend in biomedical science, and innovative in creating new approaches." Given the exponential rate of new basic biomedical discoveries and the continued pressures on the research budget, such skills will likely be strongly tested. 